\title{
Pengukuran Indeks Kepuasan Masyarakat Terhadap Pelayanan Di Badan Perencanaan Pembangunan, Penelitian dan Pengembangan Daerah Tahun 2020
}

\section{Ade Tahyan Alimudin}

\author{
Adetahyanalimudin@gmail.com
}

\begin{abstract}
The size agreed upon by the assistant is determined by the level of service recipient satisfaction. The satisfaction of beneficiaries received must be in accordance with what is needed and expected. And the government has also issued a Regulation of the Minister of Administrative Reform and Bureaucratic Reform No. 14 of 2017 concerning Guidelines for Surveying Public Satisfaction of Public Service Providers. The Elements That Are Focused In The Community Satisfaction Survey consist of 9 Elements. Of the 9 non-services in the work unit of the Regional Development Planning, Research and Development Agency in the City of Tasikmalaya in general, the Highest Average Value (NRR) The Highest Non-Service Cost Conformity (3.59), While No one has an Over Value (NRR) that almost the same but still in the GOOD category. The element with the lowest average value (NRR) is service time (average 3.07). This value reflects the highest level of satisfaction obtained from the Conformity of Service Costs. While at the time of service provides the lowest level of satisfaction. Everyone's Average Rating. Successful researcher so that BAPPELITBANGDA of Tasikmalaya City needs to strive for and maintain good service quality, as well as improve socialization for service recipients regarding the requirements and time of development planning services.
\end{abstract}

Keywords: COMMUNITY SATISFACTION INDEX, SERVICE AND BAPPELITBANGDA.

\section{PENDAHULUAN}

Pemerintah memiliki fungsi dan tujuan memberikan pelayanan kepada masyarakat, dengan menjalankan peran sebagai organisasi publik non profit yang memberikan pelayanan publik kepada masyarakat. Pelayanan publik yang diberikan didasarkan atas fungsi, peran, kewajiban dan tujuan didirikannya dalam pemenuhan kebutuhan masyarakat akan barang dan jasa yang memiliki karakteristik sebagai barang publik. Filosofi berdirinya pemerintahan memberikan pelayanan kepada masyarakat untuk memenuhi dan memfasilitasi kepentingan dan kebutuhan masyarakat akan barang atau jasa yang memiliki karakteristik barang publik yang perlu pengaturan dalam pemenuhannya. 
Memberikan pelayanan merupakan tugas utama dalam penyelenggaraan pemerintahan yang sering terlupakan akibat permasalahan yang dihadapi oleh pemerintah yang semakin rumit dan kompleks.

Meskipun fungsi utama Pemerintah memberikan pelayanan publik namun dalam pelaksanaannya pelayanan publik yang diberikan mencitrakan kredibilitas yang buruk dimana pelayanan yang diberikan selalu identik dengan prosedur yang tidak jelas dan berbelit-belit, persyaratan yang rumit dan tidak masuk akal, biaya pungutan di luar ketentuan, dan ketidakpastian penyelesaian. Pencitraan tersebut sangat erat kaitannya dengan karakteristik pelayanan publik itu sendiri, dimana Pelayanan publik cenderung bersifat monopoli dan bersifat mengatur sehingga sangat jauh dari mekanisme pasar dan persaingan. Hal ini menimbulkan dampak buruk terhadap perkembangan kualitas pelayanan yakni sering terlantarnya upaya peningkatan kualitas pelayanan dan kurang berkembangnya inovasi dalam pelayanan serta kurang terpacunya pemerintah daerah untuk memperbaiki kualitas layanan. Keadaan ini didukung oleh barang yang memiliki karakteristik public goods, dimana barang yang disediakan pemerintah pada umumnya merupakan barang yang dikonsumsi masyarakat banyak dan tingkat keterhabisannya cenderung rendah, sehingga perlu pengaturan dalam pemenuhan kebutuhan barang dengan keberadaan pemerintah menjamin pemerataan pemenuhan kebutuhan public goods tersebut. Sehingga pemerintahan dapat optimal dalam pelayanan kepada masyarakat

Menyadari pentingnya mengoptimalkan pelayanan publik bagi masyarakat, berbagai bentuk peraturan dan perundangan pun disusun. Salah satu contoh dari kepedulian tersebut adalah dikeluarkannya Undang-undang Nomor 25 Tahun 2009 tentang Pelayanan Publik. Kualitas pelayanan publik yang dilakukan oleh lembaga/ instansi pemerintahan secara umum masih belum memuaskan. Terbukti dengan masih banyaknya laporan dari masyarakat tentang maladministrasi kepada Ombudsman Republik Indonesia. Terminologi maladministrasi menjadi populer di Indonesia seiring dengan keberadaan lembaga Ombudsman Republik Indonesia. Menurut Black Law Dictionary dalam Hadjon dan Djatmiyati (2005), maladministration: poor management 
and regulation. Penjelasan lainnya diberikan oleh Hadjon (2011), maladministrasi berasal dari bahasa Latin, yakni mal malum yang berarti jelek dan administrare yang berati pelayanan, dengan demikian maladministrasi mempunyai arti pelayanan yang jelek atau buruk.

Bentuk-bentuk perbuatan yang termasuk maladministrasi yang paling umum adalah penundaan berlarut, penyalahgunaan wewenang, penyimpangan prosedur, pengabaian kewajiban hukum, tidak transparan, kelalaian, diskriminasi, tidak profesional, ketidakjelasan informasi, tindakan sewenang-wenang, ketidakpastian hukum, dan salah pengelolaan. Untuk dapat memberikan pelayanan yang memuaskan bagi pengguna jasa, penyelenggara pelayanan harus memenuhi asas-asas pelayanan sebagai berikut: transparansi, akuntabilitas, kondisional, partisipatif, kesamaan hak, dan keseimbangan hak dan kewajiban

Ukuran keberhasilan penyelenggaraan pelayanan ditentukan oleh tingkat kepuasan penerima pelayanan. Kepuasan penerima pelayanan dicapai apabila penerima pelayanan memperoleh pelayanan sesuai dengan yang dibutuhkan dan diharapkan. Dan pemerintah juga telah menerbitkan Peraturan Menteri Pendayagunaan Aparatur Negara dan Reformasi Birokrasi Nomor 14 Tahun 2017 tentang Pedoman Survei Kepuasan Masyarakat Terhadap Penyelenggara Pelayanan Publik. Kebijakan ini merespon harapan masyarakat terhadap kualitas pelayanan publik, karena hal ini dapat diketahui dari berbagai keluhan masyarakat yang disampaikan melalui media massa dan media sosial sehingga berdampak buruk terhadap pelayanan pemerintah yang menimbulkan ketidakpercayaan masyarakat.

Diantara lain adalah :

1. Indeks Kepuasan Masyarakat (IKM) adalah Data dan informasi tentang tingkat kepuasaan masyarakat yang diperoleh dari hasil pengukuran secara kuantitatif dan kualitatif atas pendapat masyarakat dalam memperoleh pelayanan dari aparatur penyelenggara pelayanan publik dengan membandingkan antara harapan dan kebutuhan.

2. Penyelenggara pelayanan publik adalah setiap institusi penyelenggara negara, korporasi, lembaga independent yang dibentuk berdasarkan undang-undang untuk kegiatan pelayanan publik, dan badan hukum lain yang dibentuk semata-mata untuk kegiatan pelayanan publik. 
3. Instansi Pemerintah adalah instansi Pemerintah pusat dan pemerintah daerah termasuk BUMN/BUMD dan BHMN.

4. Pelayanan publik adalah kegiatan atau rangkaian kegiatan dalam rangka pemenuhan kebutuhan pelayanan sesuai peraturan perundangundangan bagi setiap warga dan penduduk atas barang, jasa, dan/atau pelayanan administratif yang disediakan oleh penyelenggara pelayanan publik.

5. Unit Pelayanan Publik adalah unit kerja/kantor pelayanan pada instansi Pemerintah termasuk BUMN/BUMD dan BHMN, yang secara langsung maupun tidak langsung memberikan pelayanan kepada penerima pelayanan.

6. Pemberi Pelayanan Publik adalah pegawai instansi pemerintah yang melaksanakan tugas dan fungsi pelayanan publik sesuai dengan peraturan perundang-undangan.

7. Penerima Pelayanan Publik adalah orang, masyarakat, lembaga instansi pemerintah dan dunia usaha, yang menerima pelayanan dari aparatur penyelenggar pelayanan publik.

8. Kepuasaan Pelayanan adalah hasil pendapat dan penilaian masyarakat terhadap kinerja pelayanan yang diberikan oleh aparatur penyelenggara pelayanan publik.

9. Biaya Pelayanan Publik adalah segala biaya (dengan nama atau sebutan apapun) sebagai imbal jasa atas pemberian pelayanan publik, yang besaran dan tata cara pembayarannya ditetapkan oleh pejabat yang berwenang sesuai ketentuan peraturan perundang-undangan.

10. Unsur Pelayanan adalah Faktor atau aspek yang terdapat dalam penyelenggaraan pelayanan kepada masyarakat sebagai variabel penyusunan indeks kepuasan masyarakat untuk mengetahui kinerja.

11. Responden adalah penerima pelayanan publik yang pada saat pencacahan sedang berada di lokasi unit pelayanan, atau yang pernah menerima pelayanan dari aparatur penyelenggara pelayanan

Dari uraian di atas maka peneliti tertarik untuk mengadakan penelitian melakukan pengukuran indeks kepuasan masyarakat terhadap pelayanan perencanaan pembangunan, penelitian dan pengembangan daerah tahun 2020 sebagai upaya meningkatkan kualitas pelayanan dan 
hasil survei untuk bahan penetapan kebijakan yang perlu diambil dan langkah perbaikan pelayanan.

\section{LANDASAN TEORI}

\section{Pelayanan Publik}

Pelayanan publik dapat diartikan sebagai pemberian layanan (melayani) keperluan orang atau masyarakat yang mempunyai kepentingan pada organisasi itu sesuai dengan aturan pokok dan tata cara yang telah ditetapkan. Pemerintahan pada hakekatnya adalah pelayanan kepada masyarakat, Tidak dapat untuk melayani dirinya sendiri, tetapi untuk melayani masyarakat serta menciptakan kondisi yang memungkinkan setiap anggota masyaraakat mengembangkan kemampuan dan kreativitasnya demi mencapai tujuan bersama (Rasyid, 1998).

Pelayanan yang seharusnya ditunjukan pada masyarakat umum kadang dibalik menjadi pelayanan masyarakat terhadap negara, meskipun negara berdiri sesungguhnya adalah untuk kepentingan masyarakat yang mendirikannya. Artinya, birokrat sesungguhnya haruslah memberikan pelayanan terbaiknya kepada masyarakat. (Sinambela dkk, 2006).

Birokrasi publik harus dapat memberikan layanan publik yang lebih profesional, efektif, sederhana, transparan, terbuka, tepat waktu, responsif dan adaptif serta sekaligus dapat membangun kualitas manusia dalam arti meningkatkan kapasitas individu dan masyarakat untuk secara aktif menentukan masa depannya sendiri (Effendi dalam Widodo, 2001).

Seperti yang dikutip oleh Donald dalam Hardiyansyah (2011:10) bahwa pelayanan pada dasarnya adalah merupakan kegiatan atau manfaat yang ditawarkan oleh suatu pihak kepada pihak lain dan pada hakekatnya tidak berwujud serta tidak menghasilkan kepemilikan sesuatu, proses produksinya mungkin juga tidak dikaitkan dengan suatu produksi fisik.

Adapun pelayanan umum atau pelayanan publik menurut Wasistiono dalam Hardiyansyah (2011:11) adalah pemberian jasa, baik oleh pemerintah, pihak swasta atas nama pemerintah ataupun pihak 
swasta kepada masyarakat, dengan atau tanpa pembayaran guna memenuhi kebutuhan dan atau kepentingan masyarakat.

Sedangkan menurut Moenir (2010:26) pelayanan umum adalah kegiatan yang dilakukan oleh seorang atau sekelompok orang dengan landasan faktor materiel melalui sistem, prosedur dan metode tertentu dalam rangka usaha memenuhi kepentingan orang lain sesuai dengan haknya

\section{Kualitas Pelayanan Publik}

Kualitas pelayanan (Service Quality) seperti yang dikatakan oleh Zeithaml dalam Hardiyansyah (2011:41) adalah "kualitas pelayanan ditentukan oleh dua hal, yaitu: expected service dan perceived service. Expected service dan perceived service ditentukan oleh dimention of service quality yang terdiri dari sepuluh dimensi, yaitu: (1) Tangibles, (2) Reability, (3) Responsiveness, (4) Competence, (5) Courtesy, (6) Credibility, (7) Feel secure, (8) Acces, (9) Communication, (10) Understanding the costumer.

Dari sepuluh dimensi kualitas pelayanan tersebut, kemudian Zeithaml et.al. dalam Hardiyansyah (2011:42) menyederhanakan menjadi lima dimensi, yaitu dimensi SERVQUAL (kualitas pelayanan). Namun penulis membatasinya sesuai dengan Peraturan Pemerintah Nomor 17 Tahun 2017 tetang Pedoman Penilaian Kinerja unit Penyelenggara Pelayanan Publik

\section{Indeks Kepuasan Masyarakat (IKM)}

Secara umum indeks adalah petunjuk yang sistematik kepada satuansatuan yang terkandung di dalam, atau konsep yang diturunkan dari koleksi entitas atau basis data. Disamping itu, dalam pengertian praktis indeks juga dapat didefinisikan sebagai daftar referensi secara alfabetis yang biasanya terdapat pada bagian akhir sebuah buku. Dalam ilmu perpustakaan indeks mempunyai arti yang luas, yang secara umum dapat diartikan sebagai catatan mengenai nilai-nilai dari berbagai atribut yang diharapkan dapat digunakan sebagai dasar pencarian informasi. Sedangkan Indeks Kepuasan Masyarakat (IKM) adalah data dan informasi tentang tingkat kepuasan masyarakat yang diperoleh dari hasil 
pengukuran secara kuantitatif dan kualitatif atas pendapat masyarakat dalam memperoleh pelayanan dari aparatur penyelenggara pelayanan public dengan membandingkan antara harapan dan kebutuhannya.

Dalam Permenpan Nomor 17 Tahun 2017 disebutkan bahwa Survei Kepuasan Masyarakat (SKM) ini bertujuan untuk mengukur tingkat kepuasan masyarakat sebagai pengguna layanan dan meningkatkan kualitas penyelenggaraan pelayanan publik. Dengan sasaran :

1. Mendorong partisipasi masyarakat sebagai pengguna layanan dalam menilai kinerja penyelenggara pelayanan;

2. Mendorong penyelenggara pelayanan untuk meningkatkan kualitas pelayanan publik;

3. Mendorong penyelenggara pelayanan menjadi lebih inovatif dalam menyelenggarakan pelayanan publik;

4. Mengukur kecenderungan tingkat kepuasan masyarakat terhadap pelayanan publik.

Unsur-unsur yang menjadi fokus dalam pelaksanaan Survei Kepuasan Masyarakat terdiri dari 9 unsur yang terdiri dari :

1. Persyaratan adalah syarat yang harus dipenuhi dalam pengurusan suatu jenis pelayanan, baik persyaratan teknis maupun administratif

2. Sistem, mekanisme dan prosedur adalah tata cara pelayanan yang dilakukan bagi pemberi dan penerima pelayanan termasuk pengaduan

3. Waktu penyelesaian adalah jangka waktu yang diperlukan untuk menyelesaikan seluruh proses pelayanan dari setiap jenis pelayanan

4. Biaya/Tarif adalah ongkos yang dikenakan kepada penerima layanan dalam mengurus dan atau memperoleh pelayanan dari penyelenggara yang besarnya ditetapkan Berdasarkan kesepakatan antara penyelenggara dan masyarakat

5. Produk Spesifikasi Jenis Pelayanan adalah hasil pelayanan yang diberikan dan diterima sesuai dengan ketentuan yang ditetapkan. Produk pelayanan ini merupakan hasil dari setiap spesifikasi jenis pelayanan

6. Kompetensi Pelaksana adalah kemampuan yang harus dimiliki oleh pelaksana meliputi pengetahuan keahlian keterampilan dan pengalaman.

7. Perilaku Pelaksana adalah sikap petugas memberikan pelayanan 
8. Penanganan pengaduan, saran dan masukan adalah tata cara pelaksanaan penanganan pengaduan dan tindak lanjut

9. Sarana adalah segala sesuatu yang dapat dipakai sebagai alat dalam mencapai maksud dan tujuan. Prasarana adalah segala sesuatu yang merupakan penunjang utama terselenggaranya suatu proses (usaha,pembangunan, proyek). Sarana yang digunakan untuk benda yang bergerak (komputer,mesin) dan prasarana untuk benda yang tidak bergerak (gedung).

\section{METODE PENELITIAN}

Metode yang dipakai penulis pada penelitian ini adalah kuantitatf dan kualitatif, dimana kegiatan pengukuran Indeks Kepuasan Masyarakat dilaksanakan pada Badan Perencanaan Pembangunan, Penelitian dan Pengembangan Daerah Kota Tasikmalaya yaitu pelaksananan kegiatannya berlangsung pada bulan Pebruari 2020 dengan mengedarkan 100 (seratus) kuesioner kepada Responden yang menjadi penerima manfaat layanan pada Badan Perencanaan Pembangunan, Penelitian dan Pengembangan Daerah Kota Tasikmalaya di 36 perangkat daerah.

\section{Tahapan Kegiatan Survei}

Tahapan Survey dilakukan sebagaimana gambar berikut :

Gambar 1. Tahapan Survei
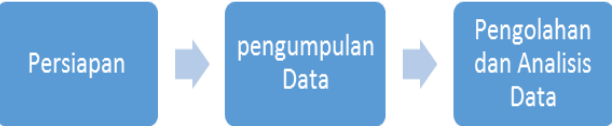

Penyusunan

Laporan

1. Persiapan, Aktivitas yang dilaksanakan pada tahap ini adalah :

a. Pembahasan Kuesioner oleh penulis dengan Kasubag. Kepegawaian dan Umum Badan Perencanaan Pembangunan, Penelitian dan Pengembangan Daerah Kota Tasikmalaya, Survei Kepuasan Masyarakat 
b. Kick-Off Meeting, penulis survei kepuasan masyarakat Badan Perencanaan Pembangunan, Penelitian dan Pengembangan Daerah untuk menyusun jadwal pengumpulan data.

c. Penyiapan Bahan :

a) Kuesioner

Dalam penyusunan Indeks Kepuasan Masyarakat (IKM) digunakan kuesioner sebagai alat bantu pengumpulan data kepuasan masyarakat penerima pelayanan. Kuesioner disusun berdasarkan tujuan survey terhadap tingkat kepuasan masyarakat.

b) Bagian dari Kuesioner Kuesioner dibagai atas 3 (tiga) bagian, yaitu : Bagian I : Identitas responden meliputi usia, jenis kelamin, pendidikan dan pekerjaan, bertujuan untuk menganalisis profil responden dalam penilaiannya terhadap unit pelayanan instansi pemerintah. Bagian II : Identitas pencacah, berisi data pencacah (apabila kuesioner diisi oleh masyarakat, bagian ini tidak diisi) Bagian III : Mutu pelayanan publik adalah pendapat penerima pelayanan yang memuat kesimpulan atau pendapat responden terhadap unsur-unsur pelayanan yang dinilai.

c) Bentuk Jawaban

Bentuk jawaban pertanyaan dari setiap unsur pelayanan secara umum mencerminkan tingkat kualitas pelayanan, yaitu dari yang sangat baik sampai dengan tidak baik. Untuk kategori tidak baik diberi nilai persepsi 1 , kurang baik diberi nilai persepsi 2, baik diberi nilai persepsi 3 , sangat baik diberi nilai persepsi 4. Penilaian terhadap unsur prosedur pelayanan, bila : 1. Diberi nilai 1 (tidak mudah) apabila pelaksanaan prosedur pelayanan tidak sederhana, alurnya tidak mudah, loket/tahapan untuk memperoleh layanan terlalu banyak, sehingga prosesnya tidak efektif. 2. Diberi nilai 2 (kurang mudah) apabila pelaksanaan prosedur pelayanan masih belum mudah, sehingga prosesnya belum efektif. 3. Diberi nilai 3 (mudah) apabila pelaksanaan prosedur pelayanan dirasa mudah, sederhana, tidak berbelit-belit tetapi masih perlu diefektifkan. 4 . Diberi nilai 4 
(sangat mudah) apabila pelaksanaan prosedur pelayanan dirasa sangat mudah, sangat sederhana, sehingga prosesnya mudah dan efektif. b) Kriteria Responden Kriteria untuk responden Indeks Kepuasan Masyarakat adalah para pengguna layanan pada Badan Perencanaan Pembangunan, Penelitian dan Pengembangan Daerah Pengguna layanan didefinisikan sebagai orang yang sedang atau pernah (paling lama dua bulan terakhir) mendapat pelayanan pada Badan Perencanaan Pembangunan, Penelitian dan Pengembangan Daerah.

d) Metode Pemilihan Responden, Responden dipilih secara simple random sampling dari semua pengguna layanan yang masuk kriteria responden disetiap lokasi penelitian.

\section{Pengumpulan Data}

Data primer dan data sekunder, data primer adalah data yang diperoleh melalui hasil penelitian langsung terhadap obyek yang diteliti. Data tersebut diperoleh melalui metode wawancara, observasi dan hasil kuesioner dari responden konsumen/masyarakat yang menggunakan jasa layanan Badan Perencanaan Pembangunan, Penelitian dan Pengembangan Daerah (BAPPELITBANGDA) Kota Tasikmalaya, Data yang dikumpulkan pula, yaitu data yang diperoleh langsung dari responden melalui wawancara tatap muka (face to face interviews) dengan menggunakan kuesioner terstruktur. Pengawasan wawancara, pemeriksaan kuesioner yang telah terkumpul, pelaksanaan backchecking kepada $100 \%$ responden dan proses validasi kuesioner. Pengumpulan data lapangan dilakukan melalui survey kepada masyarakat yang menjadi pelanggan dari instansi pelayanan umum tersebut, dengan jumlah responden adalah 100 (seratus) orang. Kegiatan pengumpulan data telah dilaksanakan dalam periode bulan pebruari 2020 .

Sedangkan data sekunder adalah data yang diperoleh dari berbagai sumber antara lain dari dokumentasi/tulisan (buku-buku, laporan-laporan, karya ilmiah dan hasil penelitian) dan dari informasi pihak-pihak yang berkaitan dengan kajian yang diteliti (uraian tugas, tata kerja dan referensi lainnya ).. 


\section{Pengolahan dan Analisis}

Data Kuesioner yang telah terisi kemudian dikumpulkan dan diolah secara kuantitatif dengan menggunakan aplikasi Excel. Proses dan analisis data sesuai dengan petunjuk dalam Peraturan Menteri PAN dan RB Nomor 17 Tahun 2017 tentang Pedoman Penyusunan Survei Kepuasan Masyarakat unit Penyelenggara Pelayanan Publik. Selain itu survei kepuasan masyarakat ini juga dapat dilakukan penyesuaian dengan kondisi spesifik unit/lembaga pelayanan yang bersangkutan, selanjutnya dapat diolah dengan uji statistik untuk memperoleh informasi yang lebih baik terhadap data yang di dapat sehingga hasil survey dapat lebih bermanfaat.

\section{Penyusunan Laporan}

Hasil survei disusun dalam bentuk Laporan yang akan menjadi dokumen penting yang menyajikan informasi tentang perkembangan pelayanan Badan Perencanaan Pembnagunan, Penelitian dan Pengembangan Daerah Kota Tasikmalaya yang diolah dan dianalisis yang dijadikan bahan dasar pengusulan peningkatan atau keperluan lain berdasarkan ketentuan yang berlaku.

\section{HASIL DAN PEMBAHASAN}

Dari keseluruhan kuesioner sebanyak 100 kuesioner dapat terisi dengan baik sehingga dapat diolah dan dianalisis lebih lanjut. Dari hasil pengolahan terhadap kuesioner yang telah terisi tersebut, diperoleh hasil sebagai berikut :

\section{Hasil Pengukuran}

Berdasarkan Peraturan Menteri Pemberdayaan Aparatur Negara Reformasi Birokrasi Nomor 14 tahun 2017 tentang Pedoman Penyusunan Survei Kepuasan Masyarakat unit penyelenggara pelayanan publik memuat 9 unsur pelayanan yang harus diukur, yaitu : persyaratan, prosedur, waktu pelayanan, biaya/tarif, produk pelayanan, kompetensi pelaksana, perilaku pelaksana, penanganan pengaduan, saran dan masukan dan sarana dan prasarana. Sebagaimana diketahui bahwa kategorisasi mutu pelayanan berdasarkan indeks adalah sebagai berikut : 


\section{Tabel 1.}

Kategorisasi Mutu Pelayanan

\begin{tabular}{|l|c|c|l|}
\hline $\begin{array}{c}\text { Nilai Interval } \\
\text { IKM }\end{array}$ & $\begin{array}{c}\text { Nilai } \\
\text { Interval } \\
\text { Konversi } \\
\text { IKM }\end{array}$ & $\begin{array}{c}\text { Mutu } \\
\text { Pelayanan }\end{array}$ & $\begin{array}{c}\text { Kinerja Unit } \\
\text { Pelayanan }\end{array}$ \\
\hline $1,00-2,59$ & $25,00-64,99$ & $\mathrm{D}$ & Tidak Baik \\
\hline $2.60-3,60$ & $65,00-76,60$ & $\mathrm{C}$ & Kurang Baik \\
\hline $3,06-3,53$ & $76,61-88,30$ & $\mathrm{~B}$ & Baik \\
\hline $3,53-4,00$ & $88,31-100,00$ & $\mathrm{~A}$ & Sangat Baik \\
\hline
\end{tabular}

Berdasarkan pengukuran terhadap kualitas 9 unsur pelayanan tersebut diperoleh hasil skor Indeks Kepuasan Masyarakat (IKM) : 80,30 dengan angka Indeks sebesar 80.30 maka kinerja unit pelayanan ini berada dalam mutu pelayanan B dengan kategori BAIK, karena berada dalam nilai interval konversi Indeks Kepuasan Masyarakat 76,61 - 88,30 sebagaimana table di atas.

\begin{tabular}{|c|l|c|c|}
\hline No. & \multicolumn{1}{|c|}{ UNSUR PELAYANAN } & \multicolumn{2}{|c|}{ NILAI RATA-RATA } \\
\hline U1 & Kesesuaian persyaratan pelayanan dengan jenis pelayanannya & 3,09 & Baik \\
\hline U2 & $\begin{array}{l}\text { Kemudahan prosedur pelayanan yang diberikan penyelenggara } \\
\text { pelayanan }\end{array}$ & 3,19 & Baik \\
\hline U3 & Kecepatan pelayanan yang diberikan penyelenggara pelayanan & 3,07 & Baik \\
\hline U4 & $\begin{array}{l}\text { Kesesuaian antara biaya yang dibayarkan dengan biaya yang } \\
\text { telah ditetapkan }\end{array}$ & 3,59 & Sangat Baik \\
\hline U5 & $\begin{array}{l}\text { Kesesuaian antara hasil pelayanan yang diberikan dengan } \\
\text { ketentuan yang telah ditetapkan/permintaan awal pelanggan }\end{array}$ & 3,28 & Sangat Baik \\
\hline U6 & Kemampuan petugas dalam memberikan pelayanan & 3,22 & Baik \\
\hline U7 & $\begin{array}{l}\text { Sikap (kesopanan dan keramahan) petugas dalam memberikan } \\
\text { pelayanan }\end{array}$ & 3,38 & Sangat Baik \\
\hline U8 & $\begin{array}{l}\text { Kesesuaian antara pelayanan yang didapat dengan maklumat } \\
\text { pelayanan (standar pelayanan yang ditetapkan) }\end{array}$ & 3,19 & Baik \\
\hline U9 & Penanganan terhadap pengaduan, saran, dan masukan & 3,19 & Baik \\
\hline
\end{tabular}

Adapun Nilai Rata-rata dari masing-masing unsur pelayanan dapat dilihat pada tabel berikut.

\section{Tabel 2}




\section{Nilai Rata-rata (NRR) dan Indeks Kepuasaan Masyarakat (IKM) 9 Unsur Pelayanan pada Badan Perencanaan Pembangunan, Penelitian dan Pengembangan Daerah}

Rata-rata nilai dari suatu unsur pelayanan menunjukkan penilaian masyarakat terhadap unsur pelayanan tersebut. Unsur-unsur pelayanan dengan nilai rata-rata atau nilai interval IKM 3,24 atau dalam posisi BAIK sehingga unsur-unsur pelayanan masih perlu ditingkatkan lagi. Dari Tabel 2 dapat dilihat bahwa terdapat unsur yang memiliki Nilai (NRR) tertinggi adalah unsur Kesesuaian Biaya/tarif Pelayanan $(3,59)$, sedangkan unsur yang lainnya memiliki nilai (NRR) yang hampir sama tetapi masih dalam kategori BAIK. Unsur dengan Nilai Rata-Rata (NRR) terendah adalah waktu pelayanan (rata-rata 3.07). Angka ini menunjukkan bahwa tingkat kepuasan pelayanan paling tinggi diperoleh dari Kesesuaian Biaya Pelayanan. Sedangkan pada Kecepatan Pelayanan memberikan tingkat kepuasaan paling rendah.

Nilai Rata-Rata semua unsur menggambarkan bahwa penilaian masyarakat terhadap unsur pelayanan pada Badan Perencanaan Pembangunan, Penelitian dan Pengembangan Daerah pada umumnya baik. Akan tetapi unsur-unsur pelayanan perlu ditingkatkan lagi kualitas pelayanannya. Dalam upaya meningkatkan kualitas pelayanan, maka yang perlu diprioritaskan adalah pada unsur yang mempunyai nilai paling rendah. Sedangkan unsur yang mempunyai nilai cukup tinggi harus tetap dipertahankan. Dari 9 (sembilan) unsur yang ditetapkan seluruhnya dapat dikategorikan sudah mencukupi unsur nilai Indeks Kepuasan Masyarakat dengan mutu pelayanan B (Baik). Proses menciptakan pelayanan publik yang berkualitas, maka 9 unsur pelayanan di atas harus diperbaiki dan ditingkatkan kembali khususnya unsur prosedur pelayanan (Penilaian rata-rata Indeks Kepuasan Masyarakat sebesar (3.24).

\section{PENUTUP}

Dari pembahasan diatas dapat diambil kesimpulan bahwa :

1. Berdasarkan pengukuran terhadap kualitas 9 unsur pelayanan tersebut diperoleh hasil skor Indeks Kepuasan Masyarakat (IKM) : 80.30 dengan angka Indeks sebesar 80.30 maka kinerja unit pelayanan ini 
berada dalam mutu pelayanan B dengan kategori BAIK, karena berada dalam nilai interval konversi Indeks Kepuasan Masyarakat $76,61-88,30$;

2. Dari 9 unsur pelayanan, Nilai Rata-rata tertinggi (NRR) tertinggi adalah unsur Kesesuaian Biaya/tarif Pelayanan $(3,59)$, sedangkan unsur yang lainnya memiliki nilai (NRR) yang hampir sama tetapi masih dalam kategori BAIK. Unsur dengan Nilai Rata-Rata (NRR) terendah adalah waktu pelayanan (rata-rata 3.07). Angka ini menunjukkan bahwa tingkat kepuasan pelayanan paling tinggi diperoleh dari Kesesuaian Biaya Pelayanan. Sedangkan pada waktu pelayanan memberikan tingkat kepuasaan paling rendah. Nilai RataRata semua unsur menggambarkan bahwa penilaian masyarakat terhadap unsur pelayanan pada Badan Perencanaan Pembangunan, Penelitian dan Pengembangan Daerah pada umumnya baik.

3. Meskipun secara umum indeks kepuasan masyarakat berkategori BAIK, namun perlu adanya perbaikan terutama dalam unsur waktu pelayanan.

\section{Saran}

1. Perlu upaya untuk mempertahankan kualitas pelayanan yang sudah baik.

2. Perlu upaya peningkatan sosialisasi kepada penerima layanan tentang persyaratan dan waktu pelayanan perencanaan pembangunan;

3. Perlu diperbaiki prosedur pelayanan perencanaan pembangunan sehingga lebih jelas, sistematis dan pasti;

4. Agar unit pelayanan pada Badan Perencanaan Pembangunan, Penelitian dan Pengembangan Daerah dapat meningkatkan mutu pelayanan dengan penyediaan sumber daya manusia yang berkompeten dan sarana prasarana yang memadai bagi pengguna pelayanan

\section{DAFTAR PUSTAKA}

A.S. Moenir, 2010. Manajemen Pelayanan Umum Di Indonesia. Bumi Aksara : Jakarta. Hlm 88.

Hadjon, Philipus M., Hukum Administrasi dan Tindak Pidana Korupsi Cetakan Kedua, Gajahmada University Press, Yogyakarta, 2012. 
Hadjon dan Djatmiyati, Tatiek Sri, Argumentasi Hukum, Gajah Mada University Press, Yogyakarta, 2005.

Hardiansyah .2011. Kualitas Pelayanan Publik. Yogyakarta: Gava Media.

Sinambela, L.P, dkk. 2006. Reformasi Pelayanan Publik: Teori, Kebijakan, dan Implementasi. Jakarta. Bumi Aksara.

Rasyid, Ryaas, 1998. Makna Pemerintahan: Tinjauan Dari Segi Etika dan Kepemimpinan, Yarif Watampone, Jakarta.

Widodo, Joko, 2001, Good Governance, Surabaya: Insan Cendekia.

(Peraturan Menteri Pendayagunaan Aparatur Negara Dan Reformasi Birokrasi Republik Indonesia Nomor 17 Tahun 2017 Tentang Pedoman Penilaian Kinerja Unit Penyelenggara Pelayanan Publik, 2017.

Peraturan Daerah Kota Tasikmalaya Nomor 7 Tahun 2017 tentang Pembentukan dan Susunan Perangkat Daerah, 2017.

Peraturan Walikota Tasikmalaya Nomor 40 Tahun 2016 Tentang Susunan Organisasi, Kedudukan, Tugas Pokok, Fungsi Dan Tata Kerja Perangkat Daerah (Pasal 95), 2016. 